\title{
KONTRUKSI FILOSOFIS PERLINDUNGAN HAK ASASI MANUSIA MINORITAS KEAGAMAAN DALAM KONSTITUSI INDONESIA
}

\author{
A. Fajruddin Fatwa \\ Fakultas Syari'ah dan Hukum UIN Sunan Ampel Surabaya | fajruddin@uin.ac.id
}

\begin{abstract}
This article focuses on presenting problem of religious minority right in Indonesia. Based on its constitution, Indonesia has equal protection for all citizens. There are some basic religion right clearly protected and presented in constitutional and criminal law. Unfortunately, violation of minority rights still continues in Indonesian life. According to research data, there are a big gap perception between government and the people. Government choose to float the norms of religious minority right protection in abstract level and most of religious minority group asked more detail and concrete norm.
\end{abstract}

Keywords: Religious minority protection, human rights, religious minority.

Abstrak: Tulisan ini memusatkan diri pada kajian permasalahan hak asasi minoritas keaamaan di Indonesia. Berdasarkan ketentuan hukum di Indonesia, beberapa hak asasi minoritas keagamaan telah diatur secara tegas dalam konstitusi dan beragam ketentuan pidana. Walaupun demikian, kekerasan terhadap hak asasi minoritas keaamaan masih terus berlangsung. Berdasarkan analisis yang dilakukan terhadap data penelitian yang berhasil dikumpulkan, terdapat perbedaan besar antara persepsi hukum yang berkembang di masyarakat dengan persepsi hukum yang dimiliki pemerintah. Kelompok keagamaan masyarakat minoritas meminta perlindungan hukum dirumuskan dengan lebih rinci dan kongkrit, sebaliknya pemerintah beranggapan beragam ketentuan hukum yang ada sudah cukup melindungi hak asasi mereka.

Kata Kunci: Perlindungan minoritas keagamaan, hak asasi manusia, kelompok minoritas keagamaan 


\section{Pendahuluan}

Kajian tentang interaksi manusia hingga saat ini tetap menarik dilakukan. Sebagian besar kalangan sepakat bahwa manusia merupakan makhluk sosial yang selalu berinteraksi dengan lingkungannya. Ciri dasar yang melekat pada manusia adalah kemampuan interaksi sosial. Walaupun demikian, tidak selamanya interaksi tersebut berjalan dengan baik. Terkadang dalam proses interaksi sosial, manusia seringkali dihadapkan dalam berbagai permasalahan yang menyebabkan munculnya konflik. Konflik ini biasanya terjadi ketika kepentingan yang dimiliki masing-masing individu saling bertentangan dan sulit dicari penyelesaiannya. Pihak yang satu menginginkan agar kepentingannya diutamakan, sedangkan pihak yang lain memiliki keinginan yang berbeda. Dari sini dapat dipahami bahwa konflik muncul bersamaan dengan hadirnya manusia. Konflik ini berkembang mengikuti perkembangan pola interaksi yang dilakukan manusia.

Pada masa agraris, yaitu masa interaksi sosial masih menggantungkan pada pola-pola kinship, ${ }^{1}$ konflik yang terjadi biasanya terkait dengan pola persaingan dalam upaya pemenuhan kebutuhan fisik dan perolehan kekayaan pribadi. ${ }^{2}$ Penyelesaian konflik yang terjadi dalam interaksi kekeluargaan, tergantung pada kewibawaan seseorang yang paling dihormati dalam kelompok dan diharapkan mampu menyelesaikan permasalahan. Metode ini terbukti efektif, sebab hubungan yang ada masih menggunakan standar kekeluargaan. ${ }^{3}$

\footnotetext{
Dalam tataran sosisologis, pola interaksi masyarakat yang demikian ini biasanya dikenal dengan sebutan pola interaksi gemeinschaft, yaitu pola interaksi yang menitik beratkan pada hubungan familistic, bersifat lokal dan mengangkat pemimpin berdasarkan kharisma. Kenneth Thomshon, the Language of Sociology, (London and New York; Routledge, 1996), 23-26. Talcot Parson, The Social System, (London and New York : Rout ledge, 1997), I 53-7.

${ }^{2}$ Kekayaan pribadi biasa diasosiasikan dengan benda materi atau simbol status sosial. Erich From, Akar Kekerasan, (Yogyakarta: Pustaka Pelajar, 200 I), 229.

${ }^{3}$ Koentjaraningrat, Pengantar IImu Antropologi, (Jakarta: Rineka Tjipta , I 98I), I 58.
} 
Seiring dengan perkembangan zaman, pola interaksi gemeinschaft tidak dapat dipertahankan lagi. Pola ini kemudian berkembang menjadi pola interaksi geselschaft, yaitu pola interaksi contractual dengan menggunakan asas manfaat demi kepentingan kelompok masing-masing. ${ }^{4}$ Pada masa inilah konflik antara kelompok mulai dikenal dan biasanya dihubungkan dengan persaingan kelas dan kolonialisasi wilayah. Pada era modern ini peningkatan intensitas konflik tidak lagi dibatasi pada akibat persaingan kelas dan kolonialisasi wilayah, konflik dunia baru seringkali kembali pada penegakan identitas ras dan budaya. ${ }^{5}$

Penegakan identitas ras pada era modern sudah tentu memiliki beragam kendala jika dibandingkan dengan masa tradisional. Interaksi global manusia memunculkan standarstandar tertentu yang harus dipahami oleh masyarakat Internasional. Identitas suku, kelompok, dan bangsa bisa jadi tenggelam dengan hadirnya identitas global yang dianut oleh masyarakat nasional. Kalangan yang tetap memegang teguh adat istiadat, kebiasaan dan kebudayaan tertentu bisa jadi dianggap sebagai kalangan minoritas yang berbeda dengan sebagian besar kelompok masyarakat lainnya. ${ }^{6}$

Makalah ini tidak akan memotret permasalahan relasi minoritas dan mayoritas secara keseluruhan dengan pendekatan multidimensional. Makalah ini akan membatasi kajian pada ketentuan hukum positif yang mengkaji perlindungan minoritas keagamaan terutama yang terdapat dalam undang-undang No 17 tahun 2007 tentang rencana pembangunan jangka panjang nasional tahun 2005-2025.

${ }^{4}$ Ibid.

${ }^{5}$ Samuel P. Hutington, The Clash of Civilizations and the Remaking of World Order, (London: Touchstone Books, 1998), 28.

${ }^{6}$ Bryan A.Garner (ed.), Black's Law Dictionary, (New York: West Group, 1999), I0 I I. 


\section{Pengaruh Mayoritas dan Minoritas Keagamaan dalam Pembentukan Hukum}

Mohammad Berween mengusulkan adanya perbedaan paradigma pada saat memahami dimensi minoritas dalam sebuah interaksi sosial. Berween menyatakan bahwa minoritas harus dilihat dari dua aspek mendasar yaitu substantial minority dan mechanical minority. Minoritas substansial adalah kalangan minoritas yang menetap dalam sebuah kelompok mayoritas. Kalangan ini memiliki kendala dalam bidang ekspresi ras, etnis dan agama. Sedangkan jenis minoritas mekanis adalah minoritas yang terjadi karena sebuah perubahan sosial di masyarakat. Kalangan minoritas mekanis seringkali terjadi pada aspek ekspresi politik, hukum dan budaya semata. ${ }^{7}$

Perbedaan kalangan minoritas dengan kalangan mayoritas sudah tentu memiliki beberapa kendala interaksi sosial. Beragam kendala tersebut bisa jadi disebabkan adanya tuntutan untuk menyesuaikan diri dengan mainstream kehidupan mayoritas. Penyesuaian ini bisa menyebabkan orang tersebut tidak mampu untuk mempraktekkan ketentuan hukum yang berasal dari daerah asal. Selain itu, terkadang norma baru yang diterima orang tersebut bertentangan dengan ketentuan hukum yang diyakini sebelumnya. ${ }^{8}$

Salah Abd al-Razq menjelaskan bahwasanya masyarakat muslim yang hidup di Eropa memiliki beragam kendala yang selalu dihadapai mereka dalam proses interaksi sosialnya. Salah mencoba mendeskripsikan bahwa permasalahan krusial yang dialami kalangan muslim di Eropa adalah kewajiban ketentuanketentuan hukum Eropa yang tidak memiliki dasar dari al-Qur'an maupun hadis, keterlibatan langsung dalam lingkup sosial politik, penyelesaian sengketa dengan tidak menggunakan hukum Islam,

\footnotetext{
7 Mohamed Berween, "Non-Muslim in the Islamic State; Majority Rule and Minority Rights" dalam The International Journal of Human Rights, Vol 10, 2, June 2006, 91-92,

8 'Abd Allah bin Mahfudz bin Bayah, Sina'ah al-fatawa wa al-Figh al-Aqalliyyah, (Libanon: Dar alMinhaj, 2008), I63-168.
} 
berperilaku dan berinteraksi sesuai dengan pola interaksi barat. Selain itu Salah menambahkan bahwa masyarakat muslim harus bergeser dari pandangan bahwa Eropa adalah negara harb, Eropa harus dianggap sebagai dar al-Salam karena tidak memerangi Islam secara langsung, ${ }^{9}$

Permasalahan yang menimpa minoritas muslim Eropa juga disampaikan oleh Jocelyne Cesari yang beranggapan bahwa hingga saat ini masyarakat muslim mengalami masalah sosial keagamaan yang serius karena perbedaan standar pemahaman hukum yang mereka miliki. Beragam kasus yang terjadi Eropa misalnya kasus Salman Rushdie, kontroversi jilbab, serangan terhadap gedung WTC serta ancaman terhadap kartunis Denmark yang menggambar nabi Muhammad adalah bukti nyata bahwa dalam keadaan tertentu doktrin yang dipahami masyarakat muslim akan selalu memiliki kemungkinan berlawanan dengan tatanan sosial masyarakat Eropa pada umumnya. ${ }^{10}$

Ahmad Imam Mawardi menyebutkan bahwa kalangan minoritas muslim yang hidup di masyarakat mayoritas non muslim memiliki beragam kendala psikologis, sosio-politik dan hukum yang tidak memungkinkan ummat Islam untuk melaksanakan ajaran agamanya secara utuh sesuai dengan ajaran agama Islam yang berkembang di kalangan negara mayoritas muslim. ${ }^{11}$ Oleh sebab itu, masyarakat muslim memerlukan ketentuan hukum khusus yang menjamin mereka mampu berinteraksi dengan lingkungan sosial mereka dengan tetap berpegang teguh pada ketentuan hukum Islam. ${ }^{12}$

Kenyataan senada juga terjadi di kalangan non muslim yang hidup di kalangan mayoritas muslim. Doktrin hukum Islam yang berkembang di masyarakat secara tegas mencantumkan adanya

\footnotetext{
${ }^{9}$ Salah Abd al-Razq, al-Islam fi Awruba, (Beirut: al-Ma'areef Forum, 20 I 0), 17-31.

10 Jocelyne Cesari, "Islam in The West; From Imigration to Global Islam" dalam Harvard Middle Eastern and Islamic Review, Vol. VIII, 2009, I48-I 50.

" Ahmad Imam Mawardi, Fiqh Minoritas: Figh Aqalliyat dan Evolusi Maqasid al-Syari'ah dari Konsep ke Pendekatan, ( Jogjakarta; LKIS, 20 I0), 4

12 'Abd Allah bin Mahfudz, Sina'ah, 167
} 
perbedaan "kasta" antara hak kewajiban kalangan muslim dengan kalangan non muslim. Kalangan non muslim memiliki beberapa kewajiban yang berbeda dengan kalangan muslim pada umumnya. Selain itu, kalangan non muslim juga dianggap memiliki beberapa keterbatasan di bidang partisipasi publik pada umumnya. ${ }^{13}$

Pandangan tentang adanya keterbatasan non muslim untuk berpartisipasi di ruang publik tentu sangat menarik dipahami. Selain tuduhan kalangan barat yang menyimpulkan kalangan muslim membatasi ruang gerak kalangan non-muslim. Para ilmuwan muslim juga terpecah dalam dua kutub utama yaitu kalangan yang menganggap ajaran agama Islam ramah terhadap minoritas non muslim dan kalangan yang menganggap bahwa ajaran Islam tidak ramah buat kalangan non muslim.

Abdullahi Ahmed an-Na'im secara tegas menyatakan bahwa praktik yang berkembang di kalangan negara Islam menunjukkan bahwa masyarakat non muslim tidak menikmati hak-hak sebagaimana kalangan mayoritas muslim pada umumnya. Sebaliknya, Karen Amstrong seorang pemikir non-muslim malah menganggap bahwa nabi Muhammad sebagai peletak dasar sendisendi keislaman adalah figur yang sangat toleran dan sangat ramah dalam memahami hak-hak asasi minoritas non muslim. Konstitusi Madinah dianggap sebagai bukti kongkrit doktrin keadilan Islam yang ditawarkan bagi masyarakat yang plural. ${ }^{14}$

Secara khusus an-Na'im malah menganggap bahwa umat Islam memiliki ambivalensi sikap terhadap hak-hak asasi manusia. Masyarakat muslim secara nyata meratifikasi bentuk-bentuk hak asasi manusia tapi tidak mampu menegakkan hak asasi manusia tersebut. Kelemahan masyarakat muslim dalam melaksanakan hak asasi manusia disebabkan oleh dua hal: Pertama, adanya kontradiksi ketentuan hukum yang dianut oleh negara muslim

\footnotetext{
${ }^{13}$ Baca al-Qur'an 3; 28

14 Muhammad Yasir Alimi, "Muhammad, a Consistent Protector of Minority Right", The Jakarta Post, 6 Februari 2012.
} 
dengan ketentuan universal manusia. Kedua, adanya kekuatan domestik dan internasional yang memaksa masyarakat muslim melaksanakan ketentuan universal hak asasi manusia dengan tidak mempedulikan tarikan berbagai tradisi keagamaan historis. ${ }^{15}$

Anggapan keterbatasan partisipasi publik kalangan minoritas non muslim dapat dilihat dari adanya batasan yang diberikan syari'ah bahwa seorang non muslim (dhimmi) hanya berhak mempraktekkan ajaran agama mereka pada domain prifat semata, kalangan non muslim tidak berhak untuk mempraktekkan ajaran agama mereka di ruang publik. ${ }^{16}$ Ajaran syari'ah Islam, menurut pendapat an-Na'im jelas menunjukkan adanya diskriminasi antara non muslim dan muslim. Seorang non muslim memiliki kebebasan untuk memeluk ajaran Islam, sebaliknya seorang muslim dilarang untuk meninggalkan ajaran agamanya dan merubah keyakinan menjadi non muslim. Selain itu, non muslim memiliki kewajiban jizyah yang tidak wajib dilakukan kalangan muslim. ${ }^{17}$

Perbedaan perlakuan yang terdapat dalam masyarakat mayoritas dan minoritas sebenarnya tidak monopoli kalangan muslim semata, problem ini juga terjadi pada kalangan non muslim. Adolf Hitler penggagas nazisme mempraktekkan perbedaan perlakuan terhadap kalangan Yahudi. Kalangan Yahudi bukan hanya dilarang mempraktekkan ajaran agamanya melainkan juga dicabut hak hidup yang seharusnya mereka miliki. ${ }^{18}$ Kalangan Yahudi hingga saat ini masih menganggap, bahwa Hitler dengan konsep semitic genocide merupakan bukti kongkrit penderitaan terburuk yang menimpa kalangan Yahudi di masa lalu.

${ }^{15}$ Abdullahi Ahmed an-Na'im, Dekonstruksi Syari'ah I, Wacana kebebasan Sipil, Hak asasi manusia dan hubungan internasional dalam Islam, (Yogjakarta; LKIS, 200 I), 340-342,

${ }^{16}$ Idem, "Religious Minorities under Islamic Law and the Limit of Cultural Relativism", dalam Journal of Human Right Quarterly 9 Vol. I, February, 1987, $10-13$.

${ }^{17}$ Idem, Human Right in the Muslim World: Socio Political Conditions and Scriptural Imperatives; a Preliminary Inquiry" dalam Harvad Human Right Journal, Vol., III, I990, 22-24.

18 Javaid Rehman, "Accomodating Religious Identities in an Islamic States: Internasional Law, Freedom of Religion and the Rights of Religious Minorities" dalam International Journal on Minority and Group Rights Vol 7, 2000, $139-149$. 
Beragam penjelasaan tentang perbedaan perlakuan dalam interaksi sosial yang diterima seseorang sebenarnya tidak seharusnya dilihat dari aspek ekspresi materiil semata. Beragam ketentuan perundangan boleh jadi telah memberikan peluang kebebasan beragama bagi seluruh masyarakat. Praktek hukum dan ketentuan hukum sebagaimana fakta yang telah disampaikan di atas bisa jadi memicu terjadinya perbedaan das sein dan das sollen sebuah ketentuan hukum. Perbedaan perlakuan seharusnya ditinjau dari kepentingan kedua belah pihak secara intensif dan mendalam. ${ }^{19}$ Kalangan minoritas harus dimintai tanggapannya tentang hak yang diterima dan kalangan mayoritas juga harus ditanyakan bagaimana hak yang telah mereka berikan buat kalangan minoritas. Oleh sebab itu, pemahaman praktik keagamaan semata dan melupakan dimensi relegiusitas yang terdiri belief, practice, knowledge, experience, dan consequences ${ }^{20}$ hanya akan memberikan gambar parsial terhadap sebuah problem sosial yang terjadi secara umum.

Peter Radan menulis sebuah buku yang secara khusus membahas tentang hubungan antara dimensi religiusitas dengan praktik hukum di suatu negara. Menurut Radan, hukum yang berkembang di dunia dewasa ini sebenarnya dipengaruhi oleh keyakinan keagamaan yang ada di negara tersebut. Walaupun terkadang secara khusus beberapa negara menyatakan bahwa hukum tidak memiliki hubungan dengan agama tertentu, Radan berhasil membuktikan bahwa hukum tersebut masih memiliki keterkaitan dengan agama yang dikenal oleh persekutuan hukum tersebut. Radan juga menjelaskan bahwa terdapat beberapa negara

19 Hal ini disebabkan oleh adanya perbedaan paradigma antara kalangan muslim dengan masyarakat sekitarnya. Jibab dianggap sebagai sebuah kewajiban yang dijalankan dengan senang hati, sebaliknya kalangan barat menganggap hal ini adalah women oppresiion, baca Joan Wallach Scott, Politic of the Veil, (Pricenton; Pricenton Univ., 2007), 20-35. Baca juga Cesari, Islam in The West, 148-150.

${ }^{20}$ Rodney Stark and Charles Y. Glock, American Piety: The Nature Of Religious Comitment, (Barkeley: University of California Perss, 1968), 12-18. Demi efektifitas pembahasan, kajian pemikiran dimensi religiusitas akan disampaikan dalam sub bab kajian teoritik saja. 
yang secara tegas menerima hukum agama sebagian dari hukum negara, walaupun praktek hukum di negara memiliki penyimpangan dari ketentuan agamanya. ${ }^{21}$

Anggapan Radan tentang pengaruh hukum agama terhadap praktik religio-politik sudah tentu tidak dapat dipandang sebelah mata. Selain memiliki konsekwensi teologis tentang adanya pembatasan "ekspresi" keagamaan tertentu yang dilakukan negara, kebijakan politik suatu negara bisa jadi memicu ketidakadilan partisipasi kelompok agama tertentu yang bertentangan dengan hukum agama yang dianut oleh negara tersebut. Perdebatan praktik religio-politik ini dapat terlihat jelas dalam konteks Indonesia. Hak dasar berserikat, berkumpul dan beribadah sesuai dengan ketentuan agama terkadang dirusak dan dihalangi oleh kelompok mayoritas. Kelompok minoritas tidak memiliki kebebasan untuk melakukan ibadah tertentu jika bertentangan dengan kehendak mayoritas.

Pandangan yang disampaikan oleh Radan ternyata juga dijelaskan secara rinci oleh Mohammad Hemmasi and Carolyn V. Prorok dalam tulisan Demographic Changes in Iran's Officially Recognized Religious Minority Populations since the Islamic Revolution, kedua tokoh ini menjelaskan bahwa walaupun secara tegas Republik Islam Iran menuliskan konstitusi agama mereka pada hukum Islam, praktik yang ada bertentangan dengan semangat hukum Islam. Konstitusi Iran secara jelas melarang kalangan minoritas penganut ajaran Baha'i melaksanakan kegiatan agamanya. Hal senada juga terjadi pada kalangan minoritas Zoroaster, Yahudi dan Kristen berhak untuk menjalankan agamanya sepanjang tidak bertentangan dengan cita-cita republik Islam Iran. ${ }^{22}$

\footnotetext{
${ }^{21}$ Peter Radan (et.all), Law and Religion, (New York: Routledge, 2005), I-8.

22 Mohammad Hemmasi and Carolyn V. Prorok, "Demographic Changes in Iran's Officially Recognized Religious Minority Populations since the Islamic Revolution" dalam Journal of African and Asian Studies, volume I, No. 2, 2002 Koninklijke Brill NV, Leiden, 63-73 baca juga pergesaran mayoritas politik sunni menjadi minoritas politik dalam Vali Nashr, "Regional
} 
Keterkaitan hukum sebuah negara dengan sebuah nilai religiusitas tertentu ternyata berakar dari pola pikir manusia yang secara naluriah membuat penilaian baik dan buruk sesuatu. Yong Huang mencoba memberikan penjelasan bahwa penilaian baik dan buruk sesuatu inilah seringkali berakar dari keyakinan religiusitas seseorang. Huang secara tegas tidak merujuk pada ketentuan religiusitas agama tertentu yang dijadikan patokan sebagai frame pembahasan baik dan buruk, Huang hanya menjelaskan bahwa agama merupakan bahasa universal yang paling mudah dipahami dan dapat diterima persekutuan hukum negara tersebut. ${ }^{23}$ Dalam konteks ini, agama tertentu yang dipeluk oleh sebagian besar kelompok sudah tentu memiliki peluang memperjuangkan "kebaikan" dibandingkan dengan agama yang dipeluk oleh kalangan minoritas.

Penjelasan yang disampaikan oleh Huang, juga disampaikan secara menarik oleh Daphna Canetti-Nisim yang menerangkan bahwa religiusitas memiliki keterkaitan dengan nilai-nilai sosiopolitik yang ada di masyarakat. Daphna beranggapan bahwa nilainilai demokratis yang terdapat dalam ranah politik suatu negara, memiliki akar historis pada keyakinan agama yang telah mereka miliki. Religiusitas dan politik memang dua hal yang berbeda, walaupun demikian dalam titik tertentu nilai-nilai politik dan agama saling memiliki pengaruh yang kuat bagi manusia. ${ }^{24}$

Hubungan erat antara dan agama sudah tentu tidak diterima bulat oleh kalangan Ilmuwan. Abdullahi Ahmed an-Naim secara tegas menolak adanya keterkaitan antara norma agama dan norma konstitusi suatu negara. Walaupun pada awalnya menolak konsep

Implications of Shi'a Revival in Iraq" dalam The Washington Quarterly, The Center for Strategic and International Studies and the Massachusetts Institute of Technology, 2004, 7-24.

23 Yong Huang, "Religious Goodness and Political Rightness: Toward a Reflective Equilibrium beyond Liberalism and Communitarism" dalam International Journal of philosophy, Vol.46. 1999. 147-148.

${ }^{24}$ Daphna Canetti-Nisim, "The Effect of Religiosity on Endorsement of Democratic Values: The Mediating Influence of Authoritarianism "dalam Journal of Political Behavior, Vol. 26, No. 4 Dec., 2004. Hal senada juga dapat ditemukan dalam buku William D. Hart, Edward Said and the Religious Effect of Culture (Cambridge; Cambridge University, 2004). 
negara sekular, pelan tapi pasti malah mempromosikan hadirnya negara sekular sebagai bentuk negara ideal pada masa modern ini. ${ }^{25}$ Dalam pandangan Abdullah Ahmed an-Naim, negara yang baik dan proporsional adalah negara yang melepaskan diri dari sekat-sekat aturan agama. Negara sekular adalah negara yang seharusnya diambil sebagai bentuk ideal dalam kehidupan masyarakat.

\section{Pembangunan Aspek Keagamaan dalam Tata Hukum Positif di Indonesia}

Walau sejak awal kehadirannya, agama dianggap sebagai isu serius dalam kehidupan beragama. Indonesia sejak awal menolak menyebut diri sebagai negara yang berdasarkan agama tertentu. Indonesia mengakomodasi aspek keagamaan dalam rancang bangun hukum positif yang dimilikinya. Dalam sebuah teori yang digagas Hazairin menyebutkan bahwa teori receptio in complexu harus dijalankan dengan kontek Receptio exit. Ketentuan keagamaan bukan hanya dilindungi sebagai grund norm sistem hukum nasional, ketentuan hukum apapun yang bertentangan dengan ketentuan hukum agama apapun yang diakui oleh pemerintah Indonesia tidak boleh diakomodasi dalam sistem hukum nasional.

Akomodasi awal terhadap ketentuan keagamaan dapat ditemukan dalam pembukaan undang-undang dasar 1945. Paragraf pertama undang-undang tersebut sejak awal menyebutkan bahwa kemerdekaan bangsa Indonesia adalah berkat rahmat tuhan yang Maha Esa. ${ }^{26}$ Selain dalam pembukaan UUD 1945, pasal 9 juga secara eksplisit menunjukkan bahwa sistem pemerintahan harus dipimpin oleh orang yang memahami dan mempraktekkan ajaran agama.

\footnotetext{
${ }^{25}$ Abdullahi Ahmed an-Naim, "Islam and the Secular State", dalam Kosmopolis Istitute, University for Humanistics, Pluralism Working Paper No I, 2009, I3-I 5.

${ }^{26}$ Pembukaan Undang-undang dasar 1945. Paragraf I.
} 
Ketentuan lebih tegas dapat ditemukan dalam pasal 29 ayat 1 dan 2 yang berbunyi :

Pasal 29

(1) Negara berdasar atas Ketuhahan Yang Maha Esa.

(2) Negara menjamin kemerdekaan tiap-tiap penduduk untuk memeluk agamanya masing-masing dan untuk beribadat menurut agamanya dan kepercayaannya itu.

Ketentuan yang terdapat dalam dua ayat tersebut menunjukkan bahwa secara tegas Indonesia adalah negara yang berdasarkan atas ketentuan-ketentuan teologis bukan hanya negara yang menganut aspek materialistis, selain itu, negara secara tegas mengakui keragaman, kebebasan dan keyakinan yang dianut oleh seluruh warga negara. Pemerintah sejak awal berusaha menyalurkannya kearah pandangan yang sehat dan kearah KeTuhanan Yang Maha Esa. Hal ini sesuai dengan ketetapan M.P.R.S. No. II/MPRS/1960, lampiran A. Bidang I, angka 6 yang mewajibkan tumbuhnya toleransi dan perlindungan hukum bagi kebebasan beragama di Indonesia.

Selain mengatur kehidupan beragama, pemerintah juga menganggap setiap pelanggaran terhadap kebebasan kehidupan beragama sebagai sebuah tindak pidana yang harus dihukum. Ketentuan hukum yang terdapat dalam Penetapan Presiden Republik Indonesia nomor 1/PNPS tahun 1965 tentang pencegahan penyalahgunaan dan/atau penodaan agama pasal 1-3 menunjukkan bahwa setiap warga negara dilarang melakukan perbuatan-perbuatan yang merusak tatanan harmonis kehidupan keberagamaan di Indonesia.

Pasal 4 ketentuan tersebutkan menyebutkan dengan jelas bahwa ada penambahan pasal terhadap ketentuan Pasal 156 UU No 1 tahun 1946 tentang Kitab undang-undang hukum pidana. Ketentuan pasal 156a menyebutkan dipidana dengan pidana penjara selama-lamanya lima tahun barangsiapa dengan sengaja di muka umum mengeluarkan perasaan atau melakukan perbuatan a) yang pada pokoknya bersifat permusuhan, penyalah-gunaan 
atau penodaan terhadap suatu agama yang dianut di Indonesia; b) dengan maksud agar supaya orang tidak menganut agama apapun juga, yang bersendikan ke-Tuhanan Yang Maha Esa.

Walaupun PNPS telah secara tegas mengatur ketentuan kehidupan beragama, ternyata ketentuan ini tidak dapat diterima oleh sebagian kalangan masyarakat Indonesia. Tahun 2009 tercatat sebagai tahun pertama kali adanya gugatan atas kehadiran PNPS tersebut. Masyarakat seakan terpecah dalam dua kelompoktentang kepastian hukum ketentuan ini. Sebagian kelompok masyarakat yang pro pemerintah menyatakan bahwa ketentuan ini masih dibutuhkan dalam tata hukum di Indonesia sebagian yang lain malah menganggap sebaliknya. Ketentuan ini adalah ketentuan darurat semata sudah seharusnya dicabut keberlakukanya dalam tata hukum positif.

Sidang diketuai Moh. Mahfud MD dan tujuh anggota. Sidang Pertama uji materi ini sudah digelar pada 17 Nopember 2009. Dalam sidang perdana itu, tim kuasa hukum yang tergabung dalam Tim Advokasi Kebebasan Beragama (TAKB) sebagai penerima kuasa pemohon dari sejumlah NGO dan tokoh-tokoh pegiat HAM mengajukan draf permohonan setebal 62 halaman. Mereka menegaskan, PNPS bertentangan dengan prinsip "Negara Hukum" sebagaimana tercantum dalam pasal 1 ayat 3 UUD 1945.Di samping itu UU ini juga muncul di masa darurat yang berarti berlaku sementara. Pemohon menegaskan pula, UU bertentangan dengan pasal 28E ayat 1 dan 2, pasal $28 \mathrm{I}$ ayat 1 , dan pasal 29 ayat 2 UUD 1945 tentang hak beragama, meyakini, menyatakan pikiran dan sikap sesuai hati nuraninya. Mengacu pada sejumlah peraturan internasional, hak-hak tersebut sudah dilindungi seperti Deklarasi Universal Hak Asasi Manusia (DUHAM) pasal 18, Kovenan Internasional tentang Hak Sipil dan Politik (ICPPR) yang diratifikasi melalui UU No. 12 tahun 2005. Choirul Anam, salah satu anggota TAKB dengan tegas meminta 
jika PNPS tak diberlakukan, dan soal kebebasan beragama berkeyakinan cukup diatur pasal 28E dan 29 Ayat 2 UUD. ${ }^{27}$

Perdebatan yang muncul medio tahun 2009 sebenarnya sudah diprediksi sejak awal dalam UU No 17 tahun 2007 tentang Rencana pembangunan jangka panjang nasional tahun 2005-2025. Lampiran Undang-undang tersebut menyatakan dalam Bab II tentang kondisi umum dinamika keagamaan di Indonesia 8 bahwa dalam bidang kesadaran melaksanakan ajaran agama dalam masyarakat tampak beragam terpecah dalam dua kelompok besar yaitu Sebagian masyarakat beragama belum menggambarkan penghayatan dan penerapan nilai-nilai ajaran agama yang dianutnya. Kehidupan beragama pada masyarakat itu masih pada tataran simbol-simbol keagamaan dan belum pada substansi nilainilai ajaran agama. Sebagian kelompok masyarakat lain yang kehidupannya sudah mendekati, bahkan sesuai dengan ajaran agama. Dengan demikian, telah tumbuh kesadaran yang kuat di kalangan pemuka agama untuk membangun harmoni sosial dan hubungan intern dan antar umat beragama yang aman, damai, dan saling menghargai. 28

Selain memetakan keragaman penganut agama, undangundang tersebut sejak awal sudah berkeinginan untuk membangun kerukunan intern dan antarumat beragama yang belum juga berhasil dengan baik, terutama di tingkat masyarakat. Ajaran agama mengenai etos kerja, penghargaan pada prestasi, dan dorongan mencapai kemajuan belum bisa diwujudkan sebagai inspirasi yang mampu menggerakkan masyarakat untuk membangun. Selain itu, pesan-pesan moral agama belum sepenuhnya dapat diwujudkan dalam kehidupan sehari-hari.

Pembangunan dinamika keagamaan juga secara implisit dapat dilihat dalam ketentuan yang terdapat dalam Sub-bab G tentang hukum dan aparatur. Pemerintah menyakini bahwa dalam

\footnotetext{
${ }^{27}$ The Wakhid Institute, Monthly Report on Religious Issues, Edisi XXVIII, Maret 20 I0, 3.

${ }^{28}$ Undang-undang No 17 tahun 2007 tentang Rencana pembangunan Jangka Panjang nasional tahun 2005-2025. Lampiran Bab II kondisi Umum, huruf A Nomor. 4.
} 
era reformasi upaya perwujudan sistem hukum nasional terus dilanjutkan mencakup beberapa hal. Pertama, pembangunan substansi hukum, baik hukum tertulis maupun hukum tidak tertulis telah mempunyai mekanisme untuk membentuk hukum nasional yang lebih baik sesuai dengan kebutuhan pembangunan dan aspirasi masyarakat, yaitu berdasarkan Undang-Undang Nomor 10 Tahun 2004 tentang Pembentukan Peraturan Perundang-undangan.

Keinginan kedua pemerintah juga terlihat pada upaya penyempurnaan struktur hukum yang lebih efektif terus dilanjutkan sejalan dengan adanya perubahan keempat UndangUndang Dasar Negara Republik Indonesia Tahun 1945. Perubahan ini bukan hanya memberikan legalisasi dibentuknya beragam lembaga hukum baru melainkan juga perubahan aspek law enforcement hukum yang sudah ada. Aspek terakhir juga menunjukkan kemungkinan keterlibatan seluruh komponen masyarakat yang mempunyai kesadaran hukum tinggi untuk mendukung pembentukan sistem hukum nasional yang dicitacitakan.

Ketiga keinginan pemerintah di atas ternyata tidak berbanding lurus dengan kemampuan merumuskan tantangan yang akan dihadapi pemerintah. Ketiga poin tersebut seakan terlupakan dalam merumuskan tantangan apa yang akan dihadapi oleh pemerintah dalam melaksanakan cita-citanya. Sub bab II.2. A tentang sosial budaya dan kehidupan beragama ternyata tidak menyentuh adanya segregasi sosial yang terjadi di masyarakat. Pemerintah hanya membuat pernyataan sederhana bahwa kendali pembangunan keagamaan hanyalah masalah aplikasi ajaran agama dalam kehidupan berbangsa dan bernegara, membangun kerukunan intern dan extern antara ummat beragama serta memberikan rasa aman dan perlindungan dari tindak kekerasan. ${ }^{29}$

\footnotetext{
${ }^{29} \mathrm{Idem}$, II.2. Tantangan huruf A angka 4.
} 
Kegagalan pemerintah dalam melakukan identifikasi tantangan tersebut semakin terlihat jelas dalam masalah hukum dan aparatur. Jika dalam bagian kondisi umum pemerintah berhasil merumuskan tiga pekerjaan rumah yang seharusnya diselesaikan dalam pembangunan nasional, maka masalah tantangan pemerintah hanya mampu melakukan dua identifikasi semata. Kemampuan preliminary mapping condition seakan terputus ketika harus melakukan logical framework approach.30 Jika pemerintah sejak awal menyadari adanya tiga masalah yang dihadapi hukum Indonesia mengapa solusi yang ditawarkan hanya ada dua. Satu masalah hukum, entah sengaja atau tidak, sengaja dibiarkan mengambang dan tidak diselesaikan.

Segregasi antara cita dan fakta pembangunan yang digagas pemerintah semakin terlihat nyata dalam rumusan bab IV tentang Arah, Tahapan, Prioritas Pembangunan yang digagas undangundang tersebut. Beragam rumusan solusi yang disampaikan ternyata semakin jauh dari kondisi faktual yang diharapkan. Indikator yang terdapat dalam rumusan "Terwujudnya masyarakat Indonesia yang berakhlak mulia, bermoral, beretika, berbudaya, dan beradab" malah tidak mencantumkan kata-kata agama dan masalah keagamaan penduduk Indonesia. Agama bukan hanya tidak dicantumkan secara eksplisit melainkan juga ditinggalkan dan diganti dengan terminologi akhlak mulia, bermoral, beretika, berbudaya, dan beradab. Akhlak mulia yang terdapat dalam masing-masing agama sudah tentu berbeda-beda. Apalagi tidak dicantumkan dan diatur secara tegas sudah tentu akan menimbulkan masalah dikemudian hari. Sebagai contoh, masalah pendirian agama adalah termasuk kriteria kemuliaan yang dimiliki oleh penganut agama manapun, ternyata pendirian

30 Istilah ini biasanya digunakan dalam merancang participatory action research, preliminary mapping condition adalah langkah awal yang digunakan untuk memetakan masalah-masalah sosial yang dihadapi masyarakat. Adapun logical framework approach konsep berfikir program kegitan yang harus bermuara pada permasalahan yang telah digali dari masyarakat. Agus Afandi (ed.), Metodologi Penelitian Transformatif, ( Surabaya; LPM IAIN Sunan Ampel Surabaya, 2012), 19-22. 
rumah Ibadah dibanyak daerah malah menyisakan konflik sosial yang berkepanjangan.

Segregasi lain terlihat lebih jelas dalam masalah rumusan pembangunan dibidang hukum. Rumusan "Terwujudnya Indonesia yang demokratis, berlandaskan hukum dan berkeadilan" berikut indikator pencapaian yang mengikutinya sama sekali tidak mencantumkan masalah aparat hukum sebagai sasaran pembangunan. Aparat penegak hukum bukan hanya ditinggalkan melainkan juga tidak dianggap sebagai arah dan tujuan pembangunan nasional. ${ }^{31}$

\section{Penutup}

Kelemahan penegakan hukum dalam perlindungan minoritas keberagamaan dalam UU No 17 tahun 2007 tentang Rencana pembangunan jangka panjang nasional tahun 2005-2025 sebenarnya terjadi karena kehidupan beragama tidak menjadi skala prioritas pembangunan yang dijalankan pemerintah. Perlindungan ini ternyata diperparah dengan kegagalan pemerintah dalam menentukan kondisi umum yang dihadapi oleh hukum Indonesia. Rumusan dalam kondisi saat undang-undang disahkan, tantangan yang dihadapi dan modal dasar yang telah dimiliki ternyata tidak menunjukkan kesatuan pembahasan. Rumusan ini semakin diperparah ketika pemerintah tidak secara tegas merumuskan aparatur hukum sebagai tujuan pembangunan nasional.

31 Undang-undang No 17 tahun 2007 tentang Rencana pembangunan Jangka Panjang nasional tahun 2005-2025. Lampiran Bab IV Arah dan tahapan dan prioritas pembangunan jangka panjang tahun 2005-2025 Huruf C angka I-5. 


\section{Daftar Pustaka}

Afandi, Agus (ed.). Metodologi Penelitian Transformatif. Surabaya: LPM IAIN Sunan Ampel Surabaya, 2012.

Alimi, Muhammad Yasir. "Muhammad, a Consistent Protector of Minority Right", The Jakarta Post, 6 Februari 2012.

Bayah, 'Abd Allah bin Mahfudz bin. Sina'ah al-Fatawa wa al-Figh alAqalliyyah. Libanon: Dar al-Minhaj, 2008.

Berween, Mohamed. "Non-Muslim in the Islamic State; Majority

Rule and Minority Rights" dalam The International Journal of Human Rights, Vol 10, 2, June 2006.

Canetti, Daphna - Nisim, "The Effect of Religiosity on Endorsement of Democratic Values: The Mediating Influence of Authoritarianism" dalam Journal of Political Behavior, Vol. 26, No. 4 Dec., 2004.

Cesari, Jocelyne. "Islam in The West; From Imigration to Global Islam" dalam Harvard Middle Eastern and Islamic Review, Vol. VIII, 2009.

From, Erich. Akar Kekerasan. Yogyakarta: Pustaka Pelajar, 2001.

Garner, Bryan A. (ed.). Black's Law Dictionary. New York: West Group, 1999.

Hart, William D. Edward Said and the Religious Effect of Culture. Cambridge; Cambridge University, 2004.

Hemmasi, Mohammad dan Carolyn V. Prorok, "Demographic Changes in Iran's Officially Recognized Religious Minority Populations since the Islamic Revolution" dalam Journal of African and Asian Studies, volume 1, No. 2, 2002 Koninklijke Brill NV, Leiden.

Huang, Yong. "Religious Goodness and Political Rightness: Toward a Reflective Equilibrium beyond Liberalism and Communitarism" dalam International Journal of philosophy, Vol. 46, 1999.

Hutington, Samuel P. The Clash of Civilizations and the Remaking of World Order. London: Touchstone Books, 1998. 
Koentjaraningrat. Pengantar ilmu Antropologi. Jakarta: Rineka Tjipta, 1981.

Mawardi, Ahmad Imam. Figh Minoritas: Figh Aqalliyat dan Evolusi Maqasid al-Syari'ah dari Konsep ke Pendekatan. Jogjakarta: LKIS, 2010.

Na'im (an-), 'Abdullahi Ahmed. "Religious Minorities under Islamic Law and the Limit of Cultural Relativism", dalam Journal of Human Right Quarterly, 9 Vol.1, February, 1987.

-------. "Human Right in the Muslim World: Socio Political Conditions and Scriptural Imperatives ; a Preliminary Inquiry" dalam Harvad Human Right Journal, Vol., III, 1990.

-------. "Islam and the Secular State", dalam Kosmopolis Istitute, University for Humanistics, Pluralism Working Paper, No 1, 2009.

-------. Dekonstruksi Syari'ah 1, Wacana kebebasan Sipil, Hak asasi manusia dan hubungan internasional dalam Islam, Yogjakarta: LKIS, 2001.

Nashr, Vali. "Regional Implications of Shi'a Revival in Iraq" dalam The Washington Quarterly, The Center for Strategic and International Studies and the Massachusetts Institute of Technology, 2004.

Parson, Talcot. The Social System. London and New York: Rout ledge, 1997.

Radan, Peter (et.all). Law and Religion. New York: Routledge, 2005.

Razq (al-), Salah Abd. al-Islam fi Awruba. Beirut: al-Ma'areef Forum, 2010.

Rehman, Javaid. "Accomodating Religious Identities in an Islamic States: Internasional Law, Freedom of Religion and the Rights of Religious Minorities" dalam International Journal on Minority and Group Rights, Vol 7, 2000.

Scott, Joan Wallach. Politic of the Veil. Pricenton: Pricenton Univ., 2007. 
Stark, Rodney dan Charles Y. Glock. American Piety: The Nature Of Religious Comitment. Barkeley: University of California Perss, 1968.

The Wakhid Institute. Monthly Report on Religious Issues. Edisi XXVIII, Maret 2010.

Thomshon, Kenneth. The Language of Sociology. London and New York: Routledge, 1996.

Undang-undang No 17 tahun 2007 tentang Rencana pembangunan Jangka Panjang Nasional tahun 2005-2025. 